\title{
Revealing Students' Environmental Habits on Electricity and Water Usage in Their Daily Life
}

\author{
Akhmad Sukri ${ }^{1, *}$, Muhammad Arief Rizka ${ }^{2}$, Marheny Lukitasari ${ }^{3}$, Elly Purwanti ${ }^{4}$, \\ Gito Hadiprayitno 5
}

\author{
${ }^{1}$ Department of Biology Education, Universitas Pendidikan Mandalika \\ ${ }^{2}$ Department of Non Formal Education, Universitas Pendidikan Mandalika \\ ${ }^{3}$ Department of Biology Education, Universitas PGRI Madiun \\ ${ }^{4}$ Department of Biology Education, Universitas Muhammadiyah Malang \\ ${ }^{5}$ Department of Biology Education, Universitas Mataram \\ *Corresponding author. Email: akhmadsukri@undikma.ac.id
}

\begin{abstract}
This study aims to (1) reveal the environmental habits of students in daily usage of electricity and water and (2) examine how demographic factors influence students' environmental habits. This research is conducted through a survey of 1.347 students from universities in Indonesia. This study uses a Likert scale questionnaire consisting of 2 statement items, namely "I turn off the electricity when not in use", and "I always turn off the water faucet when not in use" as the research instrument. Five demographic variables, namely gender, students' major, grade level, grade point average, and parental occupation, are tested to determine their effect on students' environmental habits. Inferential statistics, namely ANOVA and multiple linear regression test are used to test the variables, while descriptive statistics are used to find the frequency, mean, standard deviation, and standard error. The result shows that two variables, namely gender and students' major have a significant influence on the environmental habits of students with a contribution of $2.7 \%(\mathrm{P}<.05$, $\mathrm{R}$ square $=.027)$, while the other three variables had an insignificant impact on students' environmental habits $(\mathrm{P}>.05)$. Furthermore, the result of this study proves that (1) women have better environmental habits than men $(\mathrm{P}<.05)$, and $(2)$ students in the science education major have better environmental habits than other majors such as social humanities and non-science education $(\mathrm{P}<.05)$. This study indicates the importance of introducing and understanding the environment to foster awareness and positive behavior of students towards the environment.
\end{abstract}

Keywords: Environmental habits, electricity \& water usage

\section{INTRODUCTION}

Water is the source of life and the primary support for ecosystems which plays a role in decomposing organic matter and energy recycling [1]. Water is essential for a human and a basic need that supports human life [2][3]. Water has a biological, ecological, socio-economic, and resource role in the sustainability of life [4]. Unfortunately, water resources have been seriously degraded and threaten both humans' and animals' lives [1]. It is exacerbated by the reckless use of water and water sources, causing damage to the balance of the ecosystem of water resources which in turn disrupts the availability of water both in quantity and quality [5].

Global climate change impacts water resources in the world, including in Indonesia [6]. Moreover, the need for clean water always increases from year to year, while pollution and damage, which cause the loss of water sources, continue to occur [7]. Indonesia accounts for $6 \%$ of the world's water resources, but ironically, most of the areas in Nusa Tenggara Timur, Java, Bali, and Sulawesi experience a shortage of clean water supplies [8]. In addition to the need for water energy resources, Indonesia is also reported to lack electrical energy where demand exceeds availability [9]. Electricity is a fundamental sector that serves as the foundation for achieving development goals, increasing people's income, changing the economic structure, and improving people's welfare [10].

To face the current water and electricity crisis, we need a solution to overcome this. One of the efforts is to use water and electricity sparingly in daily life. So far, people still tend to use clean water excessively and even 
wasting it [11]. The sensible behavior in using water and electricity is reflected in environmental habits. Environmental habits are behaviors in everyday life that reflect a caring attitude towards the environment. Some researchers may classify these environmental habits into pro-environmental behavior [12][13], because 'habits' refers to a term that is widely used to predict and explain behavior [14].

It is essential to have a pro-environmental attitude, especially for teenagers. This behavior can prevent negative impacts on the environment by improving and preserving the environment [15]. In addition, the environmental habits of students in utilizing water and electricity resources in their daily life need to be explored more. It is essential to know how far the students care about their environment. Measuring student environmental habits is crucial in making regulations, especially the importance of including ecological content through education to raise awareness and positive behavior on students towards their environment. This article describes the results of measuring the environmental habits of students in their daily usage of water and electricity.

\section{METHODS}

This research uses a survey approach [16] on 1,346 students spread across Indonesia, covers the western, central and eastern parts of Indonesia. The environmental habits (EH) questionnaire is adopted from Stern [17], which has been empirically proven to have good validity and reliability. The questionnaire is further modified and adapted to the current situation in Indonesia. The questionnaire consists of two statements related to the use of water and electricity in daily life, namely EH 1 (I turn off the electricity when not in use) and EH 2 (I always turn off the water faucet when not in use). The questionnaire has five answer choices, namely $1=$ strongly disagree, 2 = disagree, 3 = indifferent, 4 = agree, and $5=$ strongly agree.

There are five demographic variables tested together to determine their effect on students' environmental habits. The variables tested are gender (male and female), students' major (science education; science; social humanities, education, and computers), students' grade level (freshman, sophomore, junior, and senior), parental occupation (civil servant, private company employees, entrepreneurs, farmers, and freelancers), and students' grade point average (low, medium and high).

Descriptive statistical analysis is performed to calculate the frequency, mean, standard deviation, and standard error [18]. Meanwhile, inferential statistical analysis is conducted to determine the effect of independent variables on students' environmental habits through multiple linear regression analysis [19]. Then, it is followed by ANOVA analysis [20] and post hoc tests
[21]. The data analysis is assisted with the SPSS for Windows program [22].

\section{RESULTS AND DISCUSSION}

\subsection{The Influence of Demographic Factors on Environmental Habits}

To determine the effect of demographic factors on environmental habits, multiple regression analysis is performed. The result of the regression analysis is shown in Table 1. Table 1 shows that the regression model can predict the influence of demographics on students environmental habits ( $\mathrm{p}<.05)$ with an effect of $2.7 \%$ (R Square $=.027$ ). Although the result of demographic factors on environmental habits is minimal, this can be used to develop students' environmental habits.

Table 1. The analysis result of the influence of demographic variables on environmental habits

\begin{tabular}{|c|c|c|c|c|c|c|c|c|c|}
\hline Model & $\begin{array}{l}\text { Sum of } \\
\text { Squares }\end{array}$ & $\mathrm{df}$ & $\begin{array}{c}\text { Mean } \\
\text { Square }\end{array}$ & $\mathrm{F}$ & Sig. & $\mathbf{R}$ & $\begin{array}{c}\mathrm{R} \\
\text { Square }\end{array}$ & $\begin{array}{l}\text { Adjusted } \\
\text { R Square }\end{array}$ & $\begin{array}{c}\text { Std. Error } \\
\text { of the } \\
\text { Estimate }\end{array}$ \\
\hline $\begin{array}{l}\text { Regression } \\
\text { Residual } \\
\text { Total }\end{array}$ & $\begin{array}{c}11.575 \\
409.585 \\
421.161\end{array}$ & $\begin{array}{c}5 \\
1341 \\
1346 \\
\end{array}$ & $\begin{array}{l}2.315 \\
.305\end{array}$ & 7.580 & $.000^{n}$ & $.166^{4 \prime}$ & .027 & .024 & .55266 \\
\hline
\end{tabular}

To determine the effect of each demographic variable on environmental habits, a regression coefficient analysis is performed which is shown in Table 2 .

Table 2. Coefficient regression analysis on demographic variables

\begin{tabular}{llcccrc}
\hline \multirow{2}{*}{ Model } & \multicolumn{2}{c}{$\begin{array}{c}\text { Unstandardized } \\
\text { Coefficients }\end{array}$} & $\begin{array}{c}\text { Standardized } \\
\text { Coefficients }\end{array}$ & \multirow{2}{*}{$\mathrm{t}$} & Sig. \\
\cline { 2 - 5 } & \multicolumn{1}{c}{$\mathrm{B}$} & Std. Error & Beta & & \\
\hline $1 \quad$ (Constant) & 4.774 & .113 & & 42.220 & .000 \\
& Gender & -.160 & .034 & -.131 & -4.761 & .000 \\
& Student's major & -.035 & .017 & -.056 & -2.017 & .044 \\
Semester & .014 & .016 & .023 & .841 & .400 \\
& GPA & .049 & .028 & .047 & 1.712 & .087 \\
& Parental_occupation & -.005 & .011 & -.012 & -.450 & .653 \\
\hline
\end{tabular}

a. Dependent Variable: EH

The result of the regression coefficient analysis shows that two variables, gender, and students' major, have a significant effect on students' environmental habits. Meanwhile, the other three variables, namely semester, GPA, and parental occupation have no effect significantly on students' environmental habits. Gender and students' major variables have negative coefficient values (-.160 and -.035). It indicates that the influence of these two variables is negative. However, negative values are irrational in this study, so that the negative value can be ignored. To determine the influence of the two demographic variables on environmental habits, a post hoc analysis is carried out, which is described as follows.

\subsection{The Influence of Gender on Environmental Habits}

To find out how gender affects environmental habits, a post hoc test is carried out and it is shown in Table 3 . 
Table 3. Post hoc analysis on the influence of gender in environmental habits

\begin{tabular}{|c|c|c|c|c|c|c|c|}
\hline Variabel & $\mathrm{N}$ & Mean & $\begin{array}{c}\text { Std. } \\
\text { Deviation }\end{array}$ & Std. Error & $\begin{array}{c}\text { Tukey } \\
\text { HSD Q } \\
\text { statistic }\end{array}$ & $\begin{array}{c}\text { Tukey } \\
\text { HSD p- } \\
\text { value }\end{array}$ & $\begin{array}{c}\text { Tukey } \\
\text { HSD } \\
\text { interference }\end{array}$ \\
\hline Female & 942 & 4.67 & .53185 & .01733 & 7.7912 & 0.0010053 & $* * \mathrm{p}<0.01$ \\
\hline Male & 405 & 4.49 & .60115 & .02987 & & \\
\hline
\end{tabular}

The post hoc analysis shown in Table 3 shows that the environmental habits scores of female students are higher than male students, with an average score of 4.67 and $4.49(\mathrm{p}<.01)$. Based on these results, both students' environmental habits scores are in a good category, which means that both male and female students have good habits, especially in their daily water and electricity usage. To obtain a more comprehensive picture related to students' responses on environmental habits especially on the daily usage of water and electricity, a descriptive analysis is carried out as shown in Figure 1.

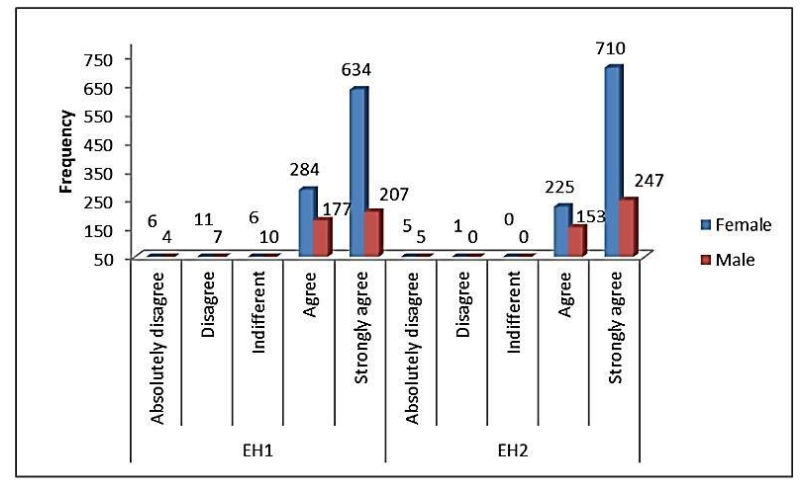

Figure 1. Students' response to their habit of water and electricity daily usage

Figure 1 shows student responses to environmental habits in daily life. This study focuses on two environmental habits, namely the daily usage of water and electricity on students. Environmental habits $(\mathrm{EH})$ consist of two statements, namely EH 1 and 2. The student responses to EH 1 (I turn off the power when not in use) vary between genders. Most female students agree and strongly agree on turning off electricity when not in use compared to male students. Likewise, EH 2 (I always turn off the water faucet when not in use) also shows that female students are more likely to choose to agree and strongly agree than male students. According to Figure 1, only a small number of respondents from both genders chose strongly disagree, disagree, and indifferent for both statements. This study reveals that the awareness of female students in daily usage of water and electricity is better than male students.

The result of this study is in line with the findings of Sugiarto \& Gabriella [23], which revealed that students have a high awareness of this matter. However, their environmental-friendly behavior is still moderate. It means that students already have awareness but in theory only, without real action to apply their knowledge. In this study, statements on EH 1 and EH 2 show attitudes that represent students' daily behavior. Students who chose to agree and strongly agree on turning off water and electricity when not in use reflect their environmentally friendly daily lives. The result of this study also strengthens previous researches, which found that women have better environmental attitudes and behaviors than men [24][25][26].

Theoretically, women are more caring, loving, and nurturing than men. On the other hand, men are more independent and competitive [24]. Furthermore, Meylan [27] explains that women can act as agents of change who can respond to environmental changes better than men because of their 'nurturing' nature. The results of this study strengthen previous research conducted by Barnas \& Ridwan [28], which found that female students had better environmental knowledge than male students. In addition, women's attitudes towards maintaining environmental cleanliness are better than men's. The high number of women's attitudes and behavior in this study is caused by internal factors as described before.

\subsection{The Influence of Student's Major on Environmental Habits}

In order to know the effect of the student's major on environmental habits, a post hoc analysis was carried out which is shown in Table 4.

Table 4. Post hoc analysis on the influence of student's major on environmental habits

\begin{tabular}{|l|l|l|l|}
\hline $\begin{array}{l}\text { treatments } \\
\text { pair }\end{array}$ & $\begin{array}{l}\text { Tukey HSD } \\
\text { Q statistic }\end{array}$ & $\begin{array}{l}\text { Tukey HSD } \\
\text { p-value }\end{array}$ & $\begin{array}{l}\text { Tukey HSD } \\
\text { inferfence }\end{array}$ \\
\hline A vs B & 2.9777 & 0.0891034 & insignificant \\
\hline A vs C & 5.2901 & 0.0010053 & $* * p<0.01$ \\
\hline B vs C & 0.6945 & 0.8627753 & insignificant \\
\hline
\end{tabular}

The post hoc analysis results in Table 4 shows that there are differences in the value of environmental habits between the three students' majors or study program, namely social humanities, education and computers major (A), science major (B), and science education major $(\mathrm{C})$. The environmental habits value for majors $\mathrm{A}$ is not significantly different B. Still, it is very different from major $\mathrm{C}$. These results indicate that students in the science education major (C) have the highest environmental habits values compared to science major (B) and social humanities major (C). The high value of environmental habits in science education department is thought to be caused by how the students in this department interact more with the environment than other majors, such as social humanities major. With this interaction, students' environmental knowledge will increase, which affects their behavior towards the environment. It is reinforced by Erdogan et al [25] which states that there is a linear connection between student activities and the environment. Students who have direct activities with the environment have better environmental knowledge than those who do not. This fact is also considered to apply to students in science major who have a lot of direct activities with the environment. The result of the post hoc analysis shows 
that there is no significant difference in the environmental habits values of students in science major and science education major.

\subsection{The Influence of Grade Level, Parental Occupation, and GPA on Environmental Habits}

The analysis in Table 2 shows that the variables of grade level or semester, parental occupation, and grade point average do not affect students' environmental habits. The result of this study contradicts the result of previous research conducted by Silalahi et al [29], which found that parental occupation affects students' environmental knowledge. This result indicates that the type of parental occupation such as civil servants, private company employees, entrepreneurs, farmers, and freelancers does not influence the environmental habits of students in daily usage of water and electricity. This result still needs to be validated further to obtain a more comprehensive picture. Likewise, the grade point average and grade level variables indicate that both variables do not affect students' environmental habits. The result of this study is contrary to previous research conducted by Şahin and Erkal [30], which found that senior students had better environmental knowledge than students from the years below them. Likewise, Bradley et al [31] found that freshmen students had better environmental knowledge than junior and senior students. The results of each research conducted by different researchers show differences. Likewise, this study also indicates that there is no influence of grade on the environmental habits of students in daily usage of water and electricity.

\section{CONCLUSION}

This study proves that demographic factors play a role in students' environmental habits. Further analysis shows that demographic factors such as gender and students' major significantly influence students' environmental habits. However, other factors such as grade level, grade point average, and parental occupation show a contrasting result. In general, female students have better behavior than male students especially in daily usage of water and electricity. Likewise with students' major, students in science major and science education major have better environmental habits than those in social and humanities major. This study indicates education in improving students' environmental habits in daily usage of water and electricity.

\section{ACKNOWLEDGMENT}

The author expresses his gratitude to BRIN KEMENDIKBUD RISTEK who has funded this research through the PTUP scheme in 2021 (Contract number: 314/E4.1/AK.04.PT/2021).

\section{REFERENCES}

[1] C. Asdak and H. Salim, "Daya Dukung Sumberdaya Air Sebagai Pertimbangan Penataan Ruang," J. Tek. Lingkung., vol. 7, no. 1, pp. 1625, 2006.

[2] S. Sangkawati and J. Hadihardaja, "Pemberdayaan Sumber Daya Air Untuk Berbagai Kepentingan Secara Berkelanjutan," Media Komun. Tek. Sipil, vol. 13, no. 3, pp. 117127, 2005.

[3] B. Sanim, "Pengelolaan Sumber daya Air dalam Menopang Negara Mandiri dan Berdaulat," KIPNAS X di Jakarta atas kerjasama Lemb. Ilmu ..., no. November, pp. 1-31, 2011.

[4] Mawardi, "Air Dan Masa Depan Kehidupan," Tarjih J. Tarjih dan Pengemb. Pemikir. Islam, vol. 12, no. 1, pp. 131-141, 2014.

[5] S. Soenyoto, "Konservasi dan Pelestarian Sumber Daya Air di Indonesia," BENTANG J. Teor. dan Terap. Bid. Rekayasa Sipil, vol. 1, no. 1, pp. 52-61, 2013.

[6] P. Rejekiningrum, "Dampak Perubahan Iklim Terhadap Sumberdaya Air: Identifikasi, Simulasi, Dan Rencana Aksi," J. Sumberd. Lahan, vol. 8, no. 1, pp. 1-15, 2014.

[7] F. Awaludin, "Permasalahan Pencemaran dan Penyediaan Air Bersih di Perkotaan dan Permasalahan Pencemaran dan Penyediaan Air Bersih di Perkotaan dan Pedesaan," no. December, pp. 0-10, 2015.

[8] A. S. Suryani, "Pembangunan Air Bersih dan Sanitasi saat Pandemi Covid-19 Clean Water and Sanitation Development during the Covid-19 Pandemic," J. Masal. Sos. |, vol. 11, no. 2, pp. 2614-5863, 2020.

[9] L. Adam, "Dinamika Sektor Kelistrikan di Indonesia," J. Ekon. dan Pembang., vol. 24, no. 1, pp. 29-41, 2016.

[10] L. Adam, "The Roles and Problems of Infrastructure in Indonesia," Econ. Financ. Indones., vol. 60, no. 1, p. 105, 2012.

[11] S. Madonna, "EFISIENSI ENERGI MELALUI PENGHEMATAN PENGGUNAAN AIR (Studi Kasus: Institusi Pendidikan Tinggi Universitas Bakrie)," J. Tek. Sipil, vol. 12, no. 4, 2016.

[12] L. Steg and C. Vlek, "Encouraging proenvironmental behaviour: An integrative review and research agenda," J. Environ. Psychol., vol. 29, no. 3, pp. 309-317, 2009.

[13] J. Krajhanzl, "Environmental and Proenvironmental Behavior," Sch. Heal. Heal. Educ. Int. Exp., vol. 21, no. September, pp. 251274, 2010.

[14] B. Gardner, "A review and analysis of the use of 'habit' in understanding, predicting and influencing health-related behaviour," Health Psychol. Rev., vol. 9, no. 3, pp. 277-295, 2015.

[15] T. Palupi and D. R. Sawitri, "The Importance of Pro-Environmental Behavior in Adolescent," 
E3S Web Conf., vol. 31, pp. 2-5, 2018.

[16] J. Ponto, "Understanding and Evaluating Survey Research.," J. Adv. Pract. Oncol., vol. 6, no. 2, pp. 168-16871, 2015.

[17] P. Stern, "Toward a coherent theory of environmentally significant behavior," J. Soc. Issues, vol. 56, no. 3, pp. 407-424, 2000.

[18] V. Kaur, P., Stoltzfus, J., \& Yellapu, "Descriptive statistics," Int. J. Acad. Med., vol. 4, no. 1, pp. 60-63, 2018.

[19] G. K. Uyanık and N. Güler, “A Study on Multiple Linear Regression Analysis," Procedia - Soc. Behav. Sci., vol. 106, pp. 234-240, 2013.

[20] G. Zwanenburg, H. C. J. Hoefsloot, J. A. Westerhuis, J. J. Jansen, and A. K. Smilde, "ANOVA-principal component analysis and ANOVA-simultaneous component analysis: A comparison," J. Chemom., vol. 25, no. 10, pp. 561-567, 2011.

[21] A. Hilton, "post hoc ANOVA tests," no. September, pp. 34-36, 2006.

[22] F. Frey, " SPSS (Software)," Int. Encycl. Commun. Res. Methods, pp. 1-2, 2017.

[23] A. Sugiarto and D. A. Gabriella, "Kesadaran Dan Perilaku Ramah Lingkungan Mahasiswa Di Kampus," J. Ilmu Sos. dan Hum., vol. 9, no. 2, p. 260, 2020.

[24] L. C. Zelezny, P. P. Chua, and C. Aldrich, "Elaborating on gender differences in environmentalism," J. Soc. Issues, vol. 56, no. 3, pp. 443-457, 2000.

[25] M. Erdogan, S. Akbunar, U. O. Asik, H. Kaplan, and C. G. Kayir, "The Effects of Demographic
Variables on Students' Responsible Environmental Behaviors," Procedia - Soc. Behav. Sci., vol. 46, no. 2, pp. 3244-3248, 2012.

[26] M. Bozoglu, A. Bilgic, B. Topuz, and Y. Ardali, "Factors Affecting the Students'Environmental Awareness, Attitudes and Behaviors in Ondokuz Mayis University, Turkey," Fresenius Environ. Bull., vol. 25, no. 4, pp. 1243-1257, 2016.

[27] M. Meylan, "PARTISIPASI PEREMPUAN DALAM PENGELOLAAN LINGKUNGAN HIDUP," Musawa, vol. 6, no. 2, pp. 236-259, 2014

[28] S. Barnas and I. M. Ridwan, "Perbedaan Gender dalam Pengetahuan, Sikap dan Perilaku Mahasiswa Pendidikan Fisika," Diffraction, vol. 1, no. 2, pp. 34-41, 2019.

[29] E. Silalahi, S. Syarifuddin, and M. Sudibyo, "Faktor-faktor yang Mempengaruhi Terhadap Pengetahuan Tentang Lingkungan pada Siswa Tingkat SMP/MTS $\mathrm{N}$ dan SMA/MAN Adiwiyata di Kota Labuhanbatu," J. Pendidik. Biol., vol. 5, no. 3, pp. 146-153, 2016.

[30] S. Şahin, H., Kılıç, İ., \& Erkal, “An Analysis of the Environmental Knowledge and Attitudes of University Students," Int. J. Interdiscip. Environ. Stud., no. February, pp. 1-10, 2012.

[31] J. C. Bradley, T. M. Waliczek, and J. M. Zajicek, "Relationship between environmental knowledge and environmental attitude of high school students," J. Environ. Educ., vol. 30, no. 3, pp. 17-21, 1999. 